\title{
První brněnské kolokvium o N. S. Leskovovi
}

\author{
Ivo Pospíšil (Brno)
}

Ústav slavistiky Filozofické fakulty Masarykovy univerzity pořádal $\mathrm{z}$ podnětu autora této zprávy první brněnské kolokvium o tvorbě Nikolaje Semjonoviče Leskova (1831-1995) určené zkušeným leskovologům i doktorandům. Kolokvium se patrně stane tradicí a dalo už podnět $\mathrm{k}$ vzniku volné Mezinárodní společnosti N. S. Leskova, která bude shromaždovat databázi leskovologických studií a překladů jeho díla z ruštiny do jiných jazyků. Tematické rozpětí bylo dáno pořadatelem takto: Nové problémy a přístupy leskovologie, Leskov v dějinách ruské literatury, Leskovova poetika, Recepce Leskova v Rusku a ve světě, Problematika překladů, Perspektivy zkoumání Leskova, Leskov v literatuře 20.-21. století, Leskov z komparatistického a genologického hlediska, Nové edice Leskova, Nové přečtení Leskova na pozadí současné literatury, Leskov a naratologie, Leskov a problém žánru na pozadí současné genologie, Leskov a metodologie literární vědy. V rámci workshopu, jenž byl součástí kolokvia, se Leskov ukázal nejen jako inspirativní objekt zkoumání, ale také jako vhodný materiál k rozvoji metodologie literární vědy a jejích jednotlivých disciplín. Kolokvium finančně podpořil grant Filozofické fakulty Masarykovy univerzity. Zahájení se ujal proděkan pro zahraniční styky FF MU Tomáš Pospíšil, jenž ocenil aktivity ústavu a organizátora ve smyslu internacionalizace humanitních věd. Účastníci si také připomněli odchod čelné ruské znalkyně Leskovova Iriny Vladimirovny Stoljarovové (1932-2017), autorky knih a studií o Leskovovi a edic jeho tvorby. Autor této zprávy vyšel ze svého díla, nebot' se Leskovem zabýval od první poloviny sedmdesátých let minulého století a později toto bádání včlenil do knih o ruské románové kronice a kronice obecně a o teorii literárních žánrů. Na kolokviu však promluvil pouze o české recepci Leskova, zejména o jeho moravském překladateli Aloisi Augustinovi Vrza- lovi (1864-1930), o němž napsal knížku (1993). Jako první vystoupila na kolokviu Marta Łukaszewicz (Varšava), která analyzovala náboženskou problematiku v Leskovově díle. Zdeněk Pechal (Olomouc) pojednal o českých pracích o Leskovovi. Alla Šelajevová (Sankt-Petěrburg), jež prezentovala nové vydání Leskovova románu Čortozy kukly (2015). Dále vystoupili její manžel Leonid Vyskočkov, historik, jenž zkoumal reflexi doby Mikuláše I. v Leskovových dílech, Anna Fedotovová (Jaroslavl'), jež pojednala o Leskovových črtách, Olha Červinskaja (Černivci) se zabývala Leskovovými alegoriemi v souvislostech skazu, Galina Kosych (Hradec Králové), která analyzovala pojetí v Meňšikovově díle, Natália Muránska se zabývala slovenským Leskovem, tedy hlavně překlady jeho děl do slovenštiny a literárněvědnou reflexí jeho díla. Majja Kučerskaja (Moskva) ukázala na parodičnost proslulého Skazu o tulském šilhavém levákovi a ocelové bleše, Lenka Paučová (Brno) ukázala na postavu Leskova v Dostojevského Deniku spisovatele, Barbara Szostek (Siedlce) zkoumala Leskovovu recepci v Polsku, Maria Długołęcka-Pietrzak (Siedlce) podrobila zkoumání hodnotový svět Leskových děl, Dorota Chmielak (Siedlce) poukázala na polskou literárněvědnou recepci Leskova a Roman Dzyk (Černivci) promluvil o ukrajinské leskovianě. Součástí programu prvního dne byla exkurze po stopách moravského překladatele Leskova a autora prvních českých dějin ruské literatury A. A. Vrzala. Vedla nejprve do budovy Petrina na Veveří ulici, sotva pár desítek, metrů od areálu Filozofické fakulty Masarykovy univerzity, kde se dřive nacházel teologický seminář a po roce 1990 krátce Biskupské gymnázium: účastníky kolokvia kompetentně prováděl ředitel instituce. $\mathrm{V}$ interiérech, k nimž přimyká malebná zahrada, přednášel Vrzal adeptům kněžství o ruské literatuře jako mnich benediktinského kláštera (opatství, dnes obnovené) v Rajhradě. Tam ostatně vedla další 
cesta účastníků kolokvia: byli tu na vysoké věcné i jazykové úrovni (česky, rusky a polsky) seznámeni s areálem kláštera, klášterní knihovnou, největší toho druhu na Moravě, a s expozicí Památníku písemnictví na Moravě. Poté položili kytičku květů na hrob A. A. Vrzala (pseudonym A. G. Stin) na místním hřbitově, kde leží spolu se svými spolubratř́mi z kláštera (Vrzal po opuštění kláštera působil jako administrátor v řadě farností, naposledy v Ostrovačicích, odkud také odešel na odpočinek na místo svého někdejšího působiště; v Rajhradě také o rok později - 1930 - umírá).
Druhý den byl kromě referátů věnován všeobecné diskusi v rámci workshopu, jíž se zúčastnili badatelé i doktorandi. Z ní byly důležité mezinárodní aspekty Leskovova díla; právě zde byly konstatovány různé bariéry, jež brání hlubšímu propojení leskovologů, včetně jazykové. Z prvního brněnského kolokvia o Leskovovi byla vydána monografická publikace. ${ }^{1}$

1 Leskov $i$ vokrug. Konteksty tvorčestva i sostojanije sovremennogo leskovedenija. Ed.: Ivo Pospísil. Brno, Ústav slavistiky Filozofické fakulty Masarykovy univerzity, Jan Sojnek Galium, 2018.

\section{prof. PhDr. Ivo Pospíšil, DrSc.}

Ústav slavistiky

Filozofická fakulta, Masarykova univerzita

Arna Nováka 1, 60200 Brno, Česká republika

ivo.pospisil@phil.muni.cz 